\title{
Malthus, the 18th Century European explorers and the principle of population in Africa
}

\author{
Georges Reniers \\ Office of Population Research, Princeton University \\ greniers@princeton.edu
}

\section{Abstract}

In the second edition of his Essay on the Principle of Population, Malthus included twelve chapters that offer a remarkable description of population dynamics from all corners of the world. His discussion of (sub-Saharan) Africa was almost entirely based on the travel accounts of James Bruce and Mungo Park, two late Eighteenth Century British explorers. In this essay, I introduce these sources and discuss the insights that Malthus did, or perhaps should have, derived from both.

\section{Introduction}

Data, instruments, and analysis techniques for studying population dynamics in Africa become ever more complex and continuously open new avenues for research. This abundance is relatively new, and it is informative as well as humbling to contrast our current scientific machinery to the resources available to our predecessors. The discussion that follows singles out one prominent benchmark in the discipline's history, namely Malthus's Second Essay - his chapter on Africa in particular, - and confronts Malthus' analysis with his sources as well as other information that was potentially available to him.

In the first edition of his Essay, published in 1798, Malthus's discussion of populations other than his own is limited. It is only from the second edition onwards (i.e., the Second Essay, published in 1803) that he included no fewer than twelve chapters that present a remarkable overview of the principle of population from all corners of the world. With one important exception, on the issue of slavery (see below), he changed only a few details in his discussion of Africa in the subsequent editions. Here, I will rely on the sixth edition; published in two volumes in 1826.

Malthus has been enormously influential - and controversial - for his thesis that population growth, when left unchecked, will outpace the growth in its means of subsistence. He further distinguishes two types of checks to population growth: positive checks, which arise from vice and misery and raise the mortality rate, ${ }^{2}$ and preventive checks, which have an effect on the birth rate and stem from either moral restraint (e.g. the delay of marriage), or again, vice $^{3}$ (Malthus, 1826). Not all of

I. This evaluation is largely confined to his discussion of sub-Saharan Africa.

2. "Under this head [...] may be enumerated all unwholesome occupations, severe labour and exposure to the seasons, extreme poverty, bad nursing of children, great towns, excesses of all kinds, the whole train of common diseases and epidemics, wars, plague and famine" (Malthus, 1826: 15). 
Malthus's ideas were necessarily new, but unlike many of his peers, Malthus's approach was more systematic and his synthesis powerful. This is, as Godelier (1983) observes, why Malthus was a scientist and many of the others were not.

Malthus's treatment of the checks to population growth in Africa is barely twenty pages long and does not occupy an important place in the development of his ideas. The fact that this and the other case studies appeared ad-hoc in his Second Essay also suggests that he merely uses them to endorse a theory that he had already outlined in the First Essay. In his discussion of Africa south of the Sahara, he primarily relies on the accounts of two late $18^{\text {th }} \mathrm{C}$. European explorers, namely James Bruce for eastern Africa and Mungo Park for western Africa (Figure I). ${ }^{4}$

\section{Malthus's sources}

James Bruce, a Scottish orientalist and explorer, traveled on his personal initiative and means through several North African and Arab countries before arriving in Abyssinia (the Ethiopian Empire) where he remained for over two years following 1769. He was the first of a new generation of explorers to travel to Africa: "neither for trade, nor for war, nor to hoist a flag, nor for the glory of God, but from curiosity"; in his par- ticular case, curiosity to discover 'the truth' about source of the Nile (Perham and Simmons, 1957: 24-25). His journey was remarkable, in part because Europeans knew little about the interior of Africa aside from the accounts of a few Jesuit missionaries in Abyssinia and Angola. The 'classical era' of African exploration that started with Bruce's travels ended with Livingstone's death about a hundred years later. The expeditions that ensued had often more explicit political motives (e.g. Stanley's voyage down the Congo in 1874) and would be followed by the colonization of many parts of Africa shortly thereafter (Perham and Simmons, 1957).

When Bruce returned to Europe, his reports were received with a mixture of enthusiasm and disbelief (Ullendorff, 1998). The skepticism may have been provoked by his ostentatious demeanor or the false claim ${ }^{5}$ that he was the first European to reach and describe the sources of the Blue Nile. His recollection of Abyssinian banquets whereby raw meat was cut from the buttocks of living cow and immediately consumed is another example of an excerpt that elicited mockery and the suspicion of embellishment (Ullendorff, 1953) (see also Figure 2). Because of the limited recognition, personal hardship, ${ }^{6}$ or both, Bruce abandoned his interest in Abyssinia for several years. It

3. "Promiscuous intercourse, unnatural passions, violations of the marriage bed, and improper arts to conceal the consequences of irregular connections, are preventive checks that clearly come under the head of vice." (Malthus, 1826: 16)

4. In his treatment of sub-Saharan Africa, he also refers once to Georges Louis Buffon's Histoire naturelle de l'homme, and in his chapter on the checks to population among the American Indians he cites François Le Vaillant's Voyage dans l'interieur de l'Afrique. Curiously, this source is not used in his chapter on Africa. Malthus also cites Volnay's

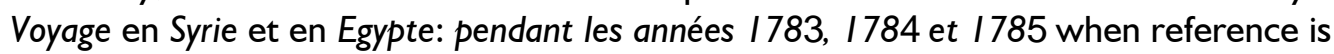
made to northern Africa.

5. Two Jesuit priests, Pedro Páez and Jerónimo Lobo, preceded him in the $17^{\text {th }}$ Century. 
is only after the death of his second spouse, twelve years following his return, that he dictates his recollections to an amanuensis and publishes an impressive five-volume account of his travels. He covers a wide array of subjects ranging from the history of Abys- sinia to its geography, botany, meteorology, his personal adventures, and the mores and manners of the people he encountered. His work has proved invaluable to contemporary historians, even though he is still not always considered a reliable storyteller
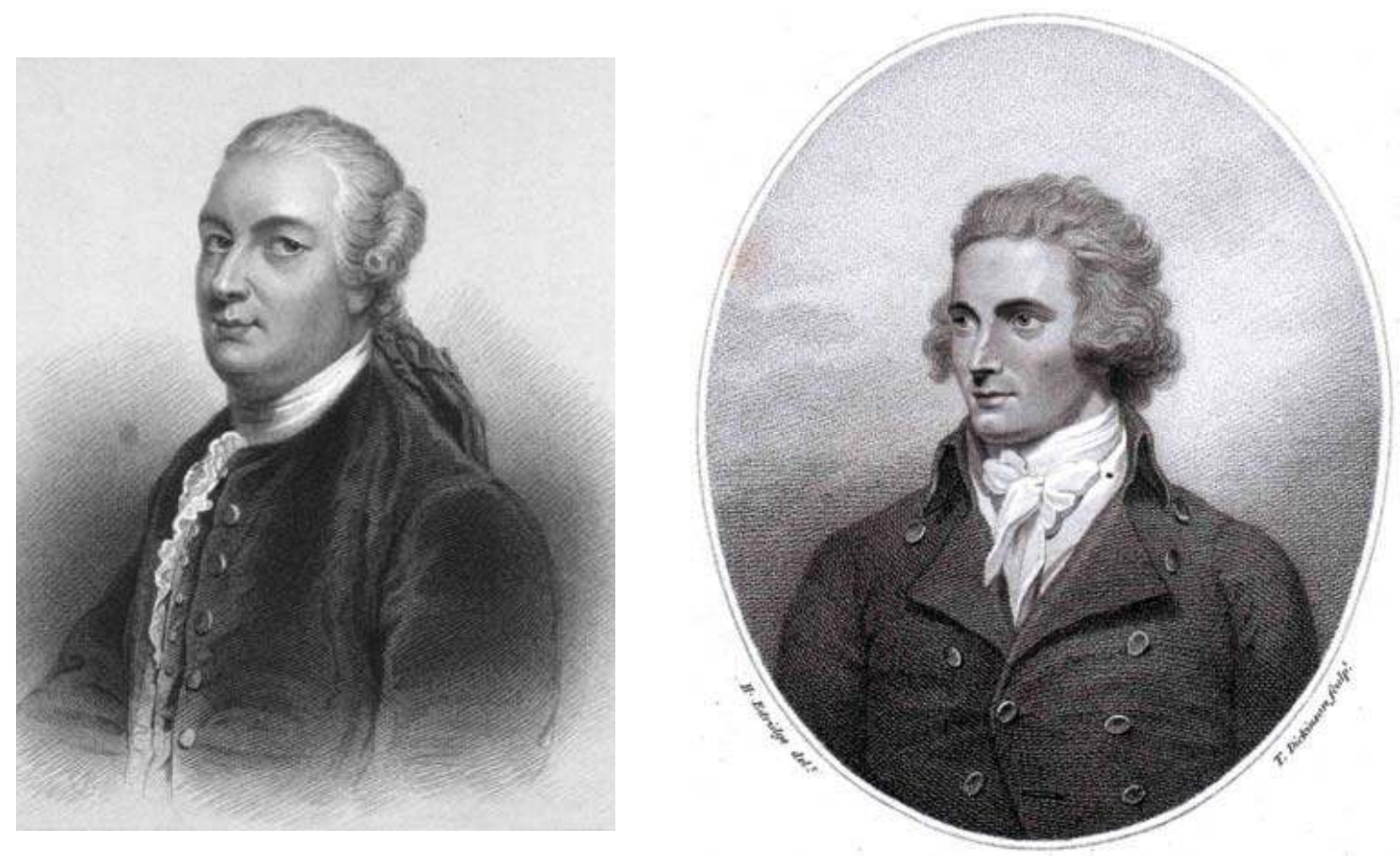

Figure I Portraits of James Bruce, I730 - 1794 (left), and Mungo Park, |77| - 1806.

Mungo Park's endeavors in the countries nowadays known as the Gambia, Senegal and Mali were not less impressive. As a trained surgeon he left under the auspices of the African Association for a solitary trip of two years (17951797) to follow the course of the Niger River. He did find the river, established that it flowed eastward, but unfortunately never reached its source. Of greater historical importance is his record of the people that he encountered. His depictions were uncharacteristically congenial for his time, and challenged the image that all natives were heathen savages. Mungo Park's simplicity and modesty yielded greater recognition of the public than did Bruce, but there are some indications that the write-up of his adventures had been subjected to censorship or selfcensorship: Joseph Banks, a key figure

6. Because of his absence for over ten years, Bruce was presumed dead and he spent considerable time and energy reclaiming his estate and possessions. In this period, Bruce also remarried and became a widower shortly thereafter. 
in the African Association, is believed to have had some influence on the format of the final product. Banks himself had previously traveled with James Cook to the islands of the Pacific, and his titillating account had been received with great indignation. The only concrete evidence of self-censorship are the recollections of Walter Scott, whom Mungo Park supposedly told that he excluded those passages that would shock the readers' credulity or render his travels more marvelous (Marsters, 2000). Mungo Park died in 1805 during his second expedition to Africa. He served throughout the $19^{\text {th }}$ century as an icon of the hero-explorer and as a model for many to follow. In accordance with the public image of the authors, Malthus treats Mungo Park's observations with the necessary respect and Bruce's account with a good dose of sarcasm and skepticism.

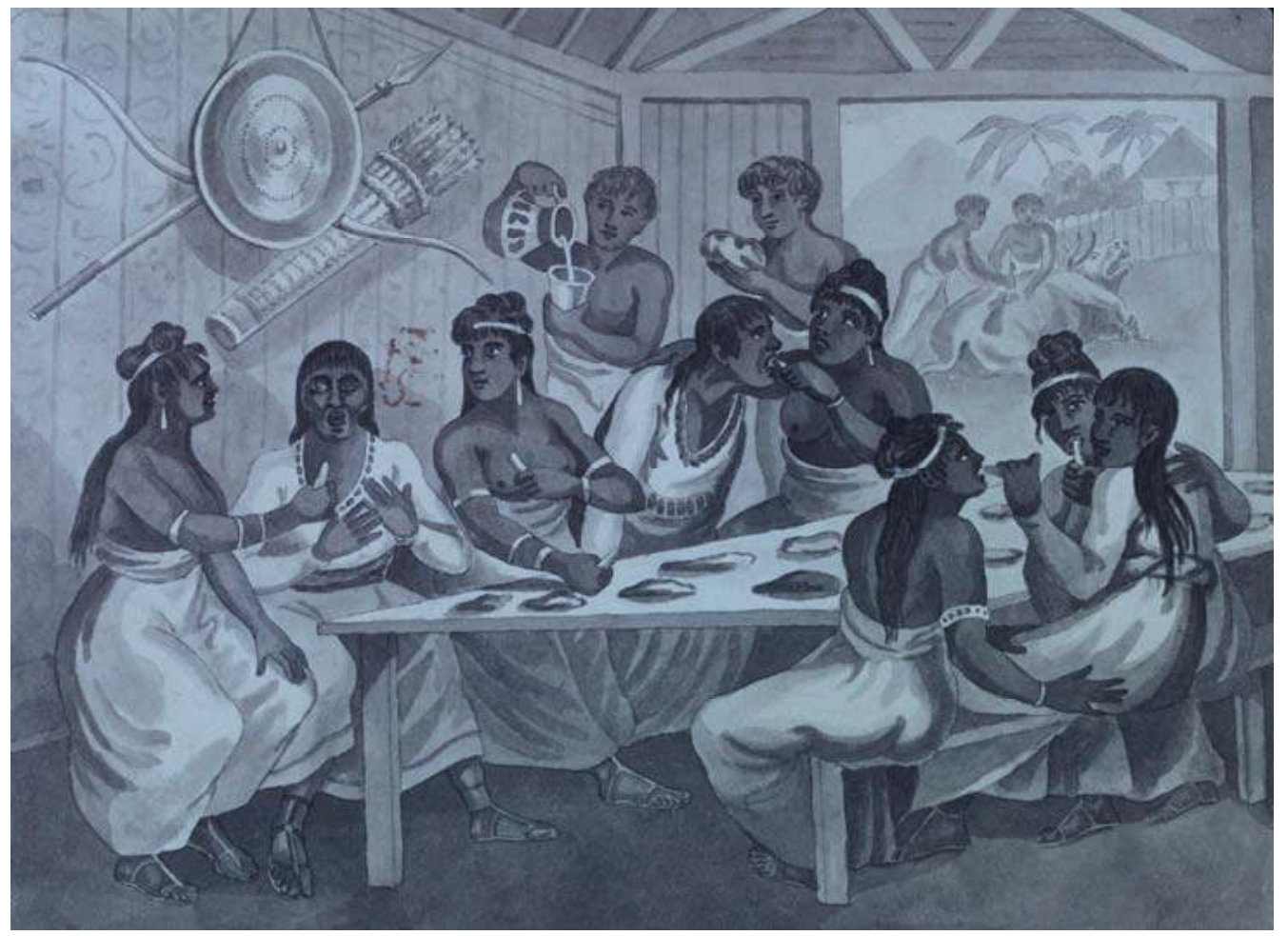

Figure 2 The Polyphemus Feast of the Abyssinians.

This illustration appeared in an abridged edition of Bruce's Travels. It is possibly based on sketches by Bruce or by his travel companion, the Italian artist Luigi Balugani. In the background, two men appear to be cutting meat from a living cow. Photo (c) Victoria and Albert Museum, London

\section{The demography of the wretched}

Just as is the case for what he calls the other less-civilized parts of the world, the take-away message from Malthus's chapter on the principle of population in Africa is that positive checks operate in full force to prevent the population 
from growing. For example:

If, in order to fill up those parts that appeared to be deficient in inhabitants, we were to suppose a high bounty given on children, the effects would probably be the increase of wars, the increase of the exportation of slaves, and a great increase of misery, but little or no increase of population (Malthus, 1826: 149-150).

To support that thesis, he relies on observations from Park and Bruce who sporadically comment on the wretched state of the population in villages tormented by warfare and famine. The occasional remarks of both explorers on the abundance of food and the fertility of the soil are less easily accommodated in Malthus's exposition, and even in these cases he refers to either warfare or plundering raids as principal destabilizing factors. These create a context of insecurity of property wherein people content themselves to subsistence agriculture. The latter is compounded by the absence of markets to sell agricultural surplus and a climate that is unfavorable to exertion (Malthus, 1826: 145-146). Despite these checks, the population occasionally grows beyond its means of subsistence with food shortages and famine as a result.

Although Malthus does not elaborate much on the root causes for the positive checks, it is of interest that he invokes the slave trade to explain the abundance of warfare and plundering. He does so in a footnote that only appeared in one of the later editions of the Second Essay:

[...] the two great requisites

[...] for a real increase of population, namely security of property, and its natural concomitant, industry, cannot be expected to exist among the negro nations, while the traffic in slaves on the coast gives such constant encouragement to the plundering excursions which Park describes (Malthus, 1826: 150).

This excerpt illustrates a few interesting points. It shows that he recognized that the positive checks to population growth were not necessarily operating under pressure of the scarcity of resources. In this case, he even seems to suggest an inverse causal order in that warfare and instability prevent the population from taking advantage of the stock of available resources and thus to grow. $^{7}$ The quote is also of interest because it highlights his stance against slavery. In an appendix to the third edition, he further denounces advocates of slavery who thought to have recognized in his exposition some intellectual support for the slave trade (see Malthus (1992). ${ }^{8}$ Malthus's stance in this matter was, however, not exceptional for his time. The abolitionist movement had considerably gained momentum in the early 1780s and the first English abolitionist laws had been passed in the early 1790s (Hallett, 1965).

7. This contrasts with the previous quote in which he suggests that population growth brings about war, an increase in the exportation of slaves, etc.

8. Proponents of the slave trade may have felt supported by Malthus's comment that "it would be difficult to find the gap that has been made by a hundred years' exportation of negroes which has blackened half America" (Malthus, 1826: 147). 


\section{Beyond positive checks}

Malthus's view on the preventive checks to population growth in Africa is not much rosier. Neither moral restraint nor any other benign fertility inhibiting factor is mentioned in his chapter on Africa and all preventive checks of importance are believed to arise from vice. This is well is well illustrated by his most distinct comment on their operation:

[...] it appears clear that few or no women lead a life of celibacy in that country [Abyssinia]; and that the prolific powers of nature are all called into action, except so far as they are checked by promiscuous intercourse. This, however, from the state of manners described by Bruce, must operate very powerfully (Malthus, I826: I56).

As was common for his time, Malthus subscribed to the view that promiscuity inhibits fertility. Aside from that, it is curious that Malthus refers to Bruce to underscore the moral corruption characterized by promiscuous intercourse because Bruce presents several counter examples, e.g.,:

I have said the Shangalla' ${ }^{9}$ have each several wives. This, however, is not owing to any inordinate propensity of the men to this gratification, but to a much nobler cause, which should make European writers, who object this to them ashamed at the injustice they do the savage, who all his life, quite the reverse of what is supposed, shews an example of the continence and chastity, which the purest and most refined European, with all the advantages of education, cannot pretend to imitate (Bruce, I790: vol. ii, 554).

Admittedly, Bruce's account contains observations that go in either direction, but Malthus uses them rather selectively, and often in support of arguments that are not always easily reconciled. In an earlier chapter on the checks to population among American Indians, he calls on Bruce to support his claim that the unfruitfulness of the population due to the lack of sexual appetite is not unique to the Americas but also common in Africa. In this case, he argues that the low sexual activity of these populations is the result of the hardships of savage life (Malthus, 1826: 38). To reconcile Malthus's seemingly contrasting positions, we need to accept that he was of the opinion that promiscuity is an innate characteristic of the less-civilized world but that lust is checked by poverty and hardship. He also critiques Buffon's allegation that African women are extremely prolific by means of a reference to an interesting passage in Mungo Park's Travels: ${ }^{10}$

The Negro women suckle their children, until they are able to

9. Shangalla comes from the Amharic word shanqella and has been used to refer to Nilotic groups west of the Blue Nile toward the Sudanese border. It may also have been used by the Semitic groups to refer to 'Negroid' groups (Ullendorff, 1998).

10. This segment is preceded by a short diversion wherein Malthus reacts skeptically to one of Buffon's other theses, that life expectancy is shortened by premature intercourse and early and excessive debauchery. Instead, he calls upon an (unspecified) analogy with nature to state that inhabitants of hot climates reach maturity earlier and thus have to perish earlier as well (Malthus, 1826: 146). 
walk of themselves. Three years nursing is not uncommon; and during this period the husband devotes his whole attention to his other wives. To this practice it is owing, I presume, that the family of each wife is seldom very numerous. Few women have more than five or six children (Park, 2000: 24I).

This fragment will undoubtedly arouse the attention of contemporary demographers because it recognizes the postpartum taboo and explicitly associates it with reduced fertility. Although this is not the only place where Malthus acknowledges the fertility inhibiting effect of breastfeeding and post-partum abstinence, " he ignores it as a preventive check of any importance. ${ }^{12}$ The quote only serves him in his negation of Buffon's proposition that African women are very prolific. Mungo Park's observation that men turn to other wives during the breastfeeding period, subsequently redirects Malthus's attention to polygyny, or, as he refers to it, polygamy.

\section{On polygyny}

Malthus's discussion of polygyny is quite interesting in its own right. Contrary to some other authors of his time, Malthus does not claim that slavery was the basis for polygyny. ${ }^{13}$ Instead, he argues that sex differences in mortality are the root cause for polygyny:

[...] the women, by leading a more sedentary life, would suffer less from the effects of a scorching sun and swampy exhalations; they would in general be more exempt from the disorders arising from debauchery; but, above all, they would escape in great measure the ravages of war. [...] The actual disproportion of the sexes arising from these causes probably first gave rise to the permission of polygamy [...] (Malthus, 1826: I5I-I52).

Bruce's suggestion that an imbalance in the sex ratio at birth lies at the basis of polygyny offers Malthus an opportunity to disparage him: ${ }^{14}$

Bruce is a great friend to polygamy, and defends it, in the only way in which it is capable of

II. He also refers to the sterility of the American Indian women during the breastfeeding period due to abstinence (Malthus, 1826: 40). As was common for his time, Malthus does not associate breastfeeding with lactational amenorrhea, but with a cultural taboo on intercourse during breastfeeding.

12. He does not mention it in the second chapter of volume I, where he discusses the general checks to population and their mode of operation.

13. To the extent that he ponders about the issue, he appears to consider polygamy as one of the causes for celibacy among slaves: "Polygamy is universally allowed among the negro nations, and consequently without a greater superabundance of women than we have reason to suppose, many will be obliged to live unmarried. This hardship will principally fall on the slaves [...]" (Malthus, I826: 146-|47)

14. This belief of an imbalance in the sex ratio at birth is not unique to Bruce. John Hippisley, an $18^{\text {th }}$ Century merchant to West Africa also claimed that an imbalance in the sex ratio at birth served as the primary reason for polygamy. In his view, the sex selective slave trade reinforced the practice of polygamy (Hippisley, 1998). 
being defended, by asserting, that in countries in which it principally prevails the proportion of girls to boys born is two or three to one. A fact so extraordinary, however, cannot be admitted upon the authority of those vague inquiries on which he founds his opinion (Malthus, 1826: 15 I).

Whereas Malthus recognizes sex differences in mortality as one of the factors facilitating polygyny, neither he nor any of his contemporaries discuss the importance of other demographic conditions that make polygynous marriage possible (e.g. age difference between spouses, the population age structure and the rapid remarriage of widows and divorcees). He does note, however, that that few women remain in a state of strict celibacy, an observation that he appears to have picked up from Bruce (Malthus, 1826: 147-153). Bruce himself elaborates on the implications of this phenomenon, and claims that it would cause the population to grow much faster - in a fourfold ratio - compared to settings where monogamy is the norm. He clarifies his position on this matter in the following manner:

For the question with regard to Arabia, and to a great part of the world besides, is, Whether or not four women and one man, married, or cohabiting at discretion, shall produce more children, than four women and one man who is debarred from cohabiting with any but one of the four, the others dying unmarried without the knowledge of men? Or, in other words, which shall have most children, one man and one woman, or one man and four women? The question, I think, needs no discussion (Bruce, 1790: vol. i, 287).

Malthus quickly disposes of the idea that polygyny could have a positive effect on population growth. Even if its effect on fertility were positive, he reasons, it would expose the population to the positive checks in an even more dramatic fashion. This comment illustrates, yet again, that Malthus conceived of positive checks as the primary regulatory mechanism to population growth in the less-civilized parts of the world.

To end Malthus's treatment of polygyny in Africa, it is worth noting that he accepts Bruce's thesis that women rather than men are most motivated to engage in polygynous relationships. Bruce argues that women generally believe that larger families protect them best in times of battle and warfare. In his view women are the main advocates of polygynous unions and are actively involved in the recruitment of co-wives, which their husbands endure with resignation. Malthus comments, however, that this extreme desire of women to have large families defeats its purpose because fewer children will grow to maturity as a consequence of the poverty and misery that ensues (Malthus, 1826: 150-15I). Malthus's position on this matter thus illustrates that he believed that positive checks operate at the population as well as household level.

\section{An assessment}

Despite three hundred years of contact, Europe's knowledge of Africa's 
interior in the $18^{\text {th }} \mathrm{C}$. was fairly limited. The topography, climate and disease environment are usually invoked to explain the deficit in European knowledge of Africa as compared to the Americas. To these reasons, Hallett adds the successful resistance of many African kingdoms against extensive exploration or settlement, and the lack of political and economic interests of European powers to venture far beyond the coastal areas (Hallett, 1965). In terms of the geographical coverage of Malthus's exposition, it is understandable that he does not cite some of the Portuguese or Arab sources for western and eastern Africa. It is more surprising, however, that he largely ignored southern Africa, which had been explored by the British as well as other Europeans ${ }^{15}$ (Hallett, 1965).

Even though they are few, Malthus's choice of sources can hardly be criticized. At the time that Malthus wrote his Second Essay, Park's account stood out because he had ventured furthest inland in West Africa. His book was also immensely popular with a broad audience. ${ }^{16}$ Bruce distinguished himself because he had compiled the most comprehensive work on sub-Saharan Africa of his time (Hallett, 1965). In contrast to many other early visitors to Africa who spent much of their time on board ships or in forts close to the coast and primarily dealt with intermediaries and slave traders, ${ }^{17}$ both Bruce and Park were relatively independent and interacted extensively with the local population; Park because he was a lightweight traveler and depended heavily on locals for his survival; Bruce because he spoke Arabic, had studied Ge'ez 18 and must have been able to engage in direct interpersonal communication with the people he met (Ullendorff, 1998).

Mary Louise Pratt (1985) classifies both authors as exponents of a sentimentalist tradition in the travel literature that she opposes to the more informational, scientistic or dry narratives wherein human presence is minimized. ${ }^{19}$ The accounts of Bruce and especially that of Park come in the format of epic style adventures where indigenous inhabitants often play important roles alongside the protagonist. Their narratives are not only more attractive, they also testify to a greater capacity for empathy. Despite the blatant ethnocentricity that was common to most of their contemporaries, both authors display a sincere and almost

15. One exception is a reference to Le Vaillant when commenting on the "phlegmatic temperament of the Hottentots as the chief reason of their thin population" (Malthus, 1826: 37). See also footnote 4. It is also curious that he only relied on Mungo Park for his description of West Africa because the number of travel accounts from that region were numerous and relatively easy accessible to the educated English public (Curtin, 1964).

16. The first 1799 edition sold out within a week and two more editions followed in the same year (Marsters, 2000: 7).

17. This is, for example, the case for De Marees, an early $17^{\text {th }} \mathrm{C}$. voyager to Guinea (De Marees, 1987)

18. Classical Ethiopian language that relates to contemporary Amharic and Tigrina as Latin does to Italian. Ge'ez is still used in the Ethiopian Orthodox Church.

19. See, for example, John Barrow's Account of the travels into the interior of southern Africa in the years 1797 and 1798. 
sociological curiosity in the manners and customs of the local population and often go on at length to disprove the harsh and sometimes fantastic prejudices that existed about Africa and its people. Their recollections are strikingly distinct from the moralistic accounts of missionaries and religious emissaries. One such example comes from Prutky, a Franciscan from Bohemia who traveled to Abyssinia on invitation of Emperor lyasu II in 1752:

In Ethiopia polygamy is forbidden by no civil law, but only by law ecclesiastical, which is not obeyed, an infringement which ought to be punished by excommunication. [...]. Thus the whole empire lives in concubinage, bigamy, adultery, and other vices, and with no pricks of conscience are sunk in the depths of sin; yet even in this socalled matrimonial bond the tie of fidelity is little observed, and either party feels itself free as occasion arises to enter into lascivious relations with others, and, although pretending faithfulness to their spouse, nonetheless carry on intrigues of illicit love, and search out the opportunity of sinning on every possible occasion. To describe this more explicitly would distress the ears of modesty, and I there- fore pass on in silence to other matters (Prutky, 1991: 238-239).

From the above, it should be clear that Bruce and Park are probably less biased observers than some of the clerics that preceded them. Despite their historical value, however, contemporary observers may be surprised by the scarcity of material both Park and Bruce offer for an analysis of population dynamics in Africa. Mungo Park makes some remarks about circumcision, marriage practices and ceremonies, but his most significant comment of demographic importance is his recognition of the post-partum taboo. ${ }^{20}$ Bruce's recollections cover a comparable range of topics, but come with stronger claims to their scientific validity as he tries to support his theses with quasi-systematic observations and numerical evidence. These are not always taken seriously by Malthus. In some cases - as with Bruce's assertions about the stark imbalance in the sex ratio at birth Malthus belittles his analysis. Malthus also selectively cites Bruce, a conclusion that is corroborated by a close reading of the sources for his chapter on Polynesia (Panoff, 1984). Finally, there is one piece of evidence that Malthus strangely enough neglects. At least three times in his account, Bruce comments on the shortness of the reproductive life span of both Ethiopian and Arab women; e.g.

They rarely are mothers after

20. Note that Park was not the first to make this observation. A decade earlier John Mattews commented that: "They never wean their children till they are able to walk, and to carry a calabash of water to their mother, which they instruct them to do as soon as possible; for, during the time a child is at the breast, the woman is not permitted to cohabit with her husband, as they suppose it would be prejudicial to her milk"(Matthews, 1788: 9899). The spoiling of the breast milk because of intercourse was also a concern in Europe at that time (Nussbaum, 1995: 82), and it is therefore not clear to what extent this comment is based on actual observation or just a European interpretation of behavior that was believed to be universal. 
22 , or begin child-bearing before they are 10; so that the time of child-bearing is but 12 years. In Europe very many examples there are of women bearing children at 14, the civil law fixes puberty at 12 , but by an innuendo seems to allow it may be something earlier. Women sometimes in Europe bear children at 50 . The scale of years of child-bearing between the savage and the European is, therefore, as is 12 to 38 (Bruce, 1790: vol. ii, 559).

Irrespective of its validity, this observation should have attracted Malthus's attention when developing a theory on the checks to population, but they are curiously enough ignored.

\section{Concluding remarks}

At the time Malthus wrote his Second Essay, there was little valuable ethnographic, let alone demographic, information available about Africa, and his two main sources were a reasonable selection representing the state of (European) knowledge about sub-Saharan Africa. Although Park's narrative may have been subject to some censorship, neither of these two travel accounts appears to have been excessively biased by a hidden political agenda (e.g. the justification of the slave trade), nor are they loaded with the moralism characteristic for many of the clerical authors. In terms of the geographic coverage, it is not clear why Malthus did not more comprehensively discuss some of the reports from trave- lers to southern Africa as they should have been available to him. It is, however, unlikely that these other sources would have contributed much to what he already learned from Bruce and Park. ${ }^{21}$

But did Malthus really learn much from Bruce and Park? This is perhaps his greatest flaw. As a reader, we never get the impression that Malthus is inductively building up a theory from his sources, nor does he rigorously test his propositions against these two "case studies'. He merely selects excerpts that are in support of his view that all regulatory mechanisms to population growth in Africa arise vice and misery. Arguments that are at odds with his synthesis of the principle of population in Africa are simply ignored or muffled away.

\section{Acknowledgements}

The idea for this essay came from interaction with the late Etienne van de Walle whose work continues to serve as an important source of inspiration. I am thankful to Richard Marcoux, Susan Watkins and the journal's reviewers for useful comments, and to Joan Donatiello for and Mary Lou Delaney for library support and editorial assistance, respectively. This manuscript was prepared with financial support from an NICHD Center Grant to the Office of Population Research (R24HD047879).

\section{References}

BRUCE, J. (1790) Travels to discover the source of the Nile, in the years 1768 , 1769, 1770, 1771, 1772, and 177ロ, 5

21. See van de Walle (1987) for a discussion of the pre-18 ${ }^{\text {th }} \mathrm{C}$. travel literature and its importance, or lack thereof, for our understanding of early population dynamics in Africa. 
volumes, Edinburgh, Printed by J. Ruthven, for G.G.J. and J. Robinson, London.

CURTIN, P. D. (1964) The Image of Africa: British ideas and action, 1780 I8\0, Volume I, Wisconsin, Wisconsin University Press.

DE MAREES, P. (1987) Description and historical account of the Gold Kingdom of Guinea (I602), VAN DANTZIG, A. and JONES, A. (eds.), Oxford, Published for British Academy by Oxford University Press.

GODELIER, M. (1983) Malthus and ethnography. IN DUPA $\square$ IER, J. (Ed.) Malthus past and present. London, Academic Press.

HALLETT, R. (1965) The penetration of Africa: European enterprise and exploration principally in northern and western Africa up to 18 $\square 0$, London,, Routledge \& K. Paul.

HIPPISLEY, J. (1998) On the populousness of Africa: an eighteenth century text. Population and Development Review, 24, 60I-608.

MALTHUS, T. R. (1826) An essay on the principle of population; or, A view of its past and present effects on human happiness; with An inquiry into our prospects respecting the future removal or mitigation of the evils which it occasions, 6th edition, Volume I, London, John Murray.

MALTHUS, T. R. (1992) An essay on the principle of population, or $A$ view of its past and present effects on human happiness; With an inquiry into our prospects respecting the future removal or mitigation of the evils which it occasions, James, P. (ed.), Cambridge, Cambridge University Press.

MARSTERS, K. F. (2000) Introduction,
IN PARK, M. Travels in the interior districts of Africa. MARSTERS, K.F. (ed.), Durham, NC, Duke University Press.

MATTHEWS, J. (I788) A voyage to the river Sierra-Leone, on the coast of Africa; containing an account of the trade and productions of the country, and of the civil and religious customs and manners of the people; in a series of letters to a friend in England, London, B. White and Son, and J. Sewell.

NUSSBAUM, F. (1995) Torrid zones: maternity, sexuality, and empire in eighteenth-century English narratives, Baltimore, MD, Johns Hopkins University Press.

PANKHURST, R. (1990) A social history of Ethiopia: the northern and central highlands from early medieval times to the rise of emperor Téwodros II. Journal of the Royal Asiatic Society, 2, 6I-63.

PANOFF, M. (1984) Malthus devant les insulaires du pacifique. IN FAUVECHAMOUX, A. (Ed.) Malthus hier et aujourd'hui. Paris, Editions du Centre National de la Recherche Scientifique.

PARK, M. (2000) Travels in the interior districts of Africa, MARSTERS, K.F. (ed.), Durham, NC, Duke University Press.

PERHAM, M. \& SIMMONS, J. (1957) African discovery: an anthology of explorations, London, Faber and Faber.

PRATT, M. L. (1985) Scratches on the face of the country; or, what Mr. Barrow saw in the land of the Bushmen. IN GATES, H. L. (Ed.) "Race," writing and difference. Chicago, Chicago University Press. 
PRUTKY, R. (199I) Prutky's travels in Ethiopia and other countries, ARROWSMITH-BROWN, J.H. (ed.), London, Hakluyt Society.

ULLENDORFF, E. (1953) James Bruce of Kinnaird. The Scottish Historical Review, 32, I28-143.

ULLENDORFF, E. (1998) The Ethiopians: an introduction to country and people Kingston, Headstart. VAN DE WALLE, E. (1987) African nuptiality before 1800 as seen through the eyes of European Observers. 2e Congrès International de Démographie Historique. Paris, Société de Démographie Historique, June 4-6. 